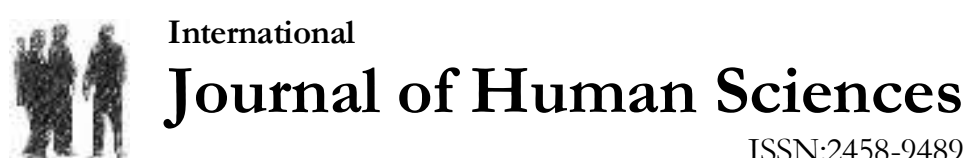

Volume 14 Issue 4 Year: 2017

\section{Micro sociological syndromes}

\author{
Özlem Aydoğmuş Ördem ${ }^{1}$
}

\begin{abstract}
With the emergence of postmodernist and poststructuralist theories, studies on micro sociology have begun to gain importance in recent years. Contrary to research on general societal structures, micro sociological studies attempt to understand how individuals or small groups are affected by micro-environment, general macro-sociological structures and socialization processes such as family and relatives, and these processes. This study examined the micro-sociological processes in which a participant lived in 16 years. The research method is composed of longitudinal idiographic technique. The data were obtained by log keeping and interview methods. The study shows that the participant experienced severe syndrome at the micro sociological level. The family showed that the participant did not agree with the values of friends, relatives and general social structure, and that they were in conflict. The findings were interpreted within the framework of the concepts of social dialogue and ambivalence. These two concepts were analyzed on the basis of postmodernist and poststructuralist theories and the data of participants were analyzed.
\end{abstract}

Keywords: Syndrome; ambivalence; social dialogue; postmodernism; poststructuralism.

\section{Introduction}

Researchers in the movement of postmodernism and poststructuralism call our era an age of ambivalence (Bauman, 2003; Inglehart \& Welzel, 2005; Newman, 2001; Sarup, 1993; Williams, 2005). There has been mounting research into a new understanding in postmodernist and poststructuralist approaches in which positivism is criticized, theories are rejected, the subject is questioned, and macro-level social structures are corrupted. Foucault's two books, I, Pierre Riviere, Having Slaughtered My Mother, My Sister, and My Brother: A Case of Parricide in the 19th Century and Discourse and Truth: the Problematization of Parrhesia, are micro-works in this way. Bauman emphasizes that 'the ambivalence is a typical modern practice', and that 'modern politics is the essence of modern thinking and modern life' (2013: 18). Bauman (2003) argues that this ambivalence is linear and normal. As the society is increasingly classified, each classification causes the ambivalence to increase. Because, according to Bauman (2003), every sort contains classification. Simmel (1999), on the other hand, prefer socialization rather than society. Simmel (1999) assumes that social interaction may influence individuals. Simmel has studied socialization processes of individuals by conducting micro sociological studies. Similarly, Foucault (2000a, 2000b, 2000c, and 2000d) similarly explains the process of subjectivization of the individual in society by studying specific groups, institutions, and subjects from macro sociological structures. Various discourses created by authority are often reinforced. Therefore, people encounter the risk of reaching their individual and social autonomy and have the problem of self-expression

\footnotetext{
${ }^{1}$ Asisst. Prof. Dr., Cukurova University, Faculty of Communication, ozlemordem@gmail.com
} 
Aydoğmuş Ördem, Ö. (2017). Micro sociological syndromes. Journal of Human Sciences, 14(4), $3905-3912$. doi:10.14687/jhs.v14i4.4953

(Inglehart, \& Welzel, 2005). Discussing Foucault's power relations, Falzon (2001) focuses on the concept of social dialogue that denotes power relations exercised by authority. Falzon (2006) says that social dialogue can be defined as favorable discursive practices. Discourses in poststructuralism are often associated with power and power relations that are criticized to emphasize subjectivity (Newman, 2001). Therefore, power and domination become the central foci of poststructuralism because it is power that generates subject (Foucault, 2000a; Newman, 2001).Criticisms of modernism and emergence of postmodernism and poststructuralism have produced several important concepts such as social dialogue, syndrome and ambivalence. These three concepts can be used as useful tools that can help analyze individuals' syndromes on a sociological level because each individual problem may not be solved on a psychological level. Syndrome can be reinterpreted within sociology based on Bauman's idea of ambivalence and Foucault' theory of power relations.

\section{Social Dialogue}

Foucault (1980 and 1984) attempts to understand the subject theory through social dialogue concept developed by Falzon (2001). In this sense, the concept of social dialogue is an important concept in terms of both social interaction and Foucault's conceptions of subjectivity in Simmel (1999). Social dialogue is a concept that can effectively explain the process of subjectivity because it involves fighting, fighting, inviting transformation and openness (Falzon, 2001, Freire, 1970). Collecting involves looking at the values in society and the system in a critical way. Individuals do not accept social values and structures as they are, and in a sense oppose power at a micro level. In this sense, social dialogue involves encountering peers in life and is a process in which actors are not easily submissive to each other, are confronted with each other and try to influence each other when necessary. Social dialogue (Falzon, 2001) is a subjective and transformative experience. Contrary to Parsons' (1961) review, it contains a contradiction. Social dialogue does not include a whole-of-the-art idea because it breaks down the meaning and meaning of the subjects, and looks at the criticality of reconciliation as risky. The subjects always resist each other. This idea is included in Simmel (1999) because Simmel tries to understand socialization through dialectics and antinomies. Therefore, antagonism is the basic principle of being a society and being social. Contrary to Parsons' (1961) holistic approach, poststructuralist and postmodernist considerations are fragmented and open to interpretation. Micro-sociologically, subjects who engage in dialogue with the family and the immediate surroundings act as non-submissive beings to other subjects. The subject is always on the move and his discourse may conflict with the general values of society. The discourse can be constantly reinterpreted in society, so the subject never changes and change.

\section{Syndrome}

The Greek word for syndrome refers to the way in which a number of ways join together or together. Serif Mardin was the sociologist who brought the concept of syndrome to the field. Mardin (1999) conceptualizes Bihruz Bey Syndrome to question the extreme westernization in Ottoman society, material consumption, dubiousness and moral decadence. The syndrome in general is a combination of several unrelated phenomena or phenomena and manifests itself as a single phenomenon. Although the syndrome is mainly used in the fields of medicine, psychology, biology and psychiatry, it can be thought that this concept can be used in sociology. Because the psychological syndrome is insufficient to explain some cases, a sociological view of the syndrome seems necessary. The fact that Mardin has applied the syndrome concept to sociology a long time ago shows that such a concept can be used more efficiently and conveniently. This study will try to explain that individuals are sociologically based when experiencing syndrome.

\section{Ambivalence}

In the field of sociology, postmodernism and postmodernism, which are seen as a critique of modernism, have brought new concepts and problems. One of these concepts is the concept of ambivalence. Bauman theorizes the concept of ambivalence. Bauman (1999) states that 'ambivalence is something we have created, not something we have created, but something we have 
Aydoğmuş Ördem, Ö. (2017). Micro sociological syndromes. Journal of Human Sciences, 14(4), $3905-3912$. doi:10.14687/jhs.v14i4.4953

created through our efforts to repair it, which we have created all over again and in greater quantities' (154). Ambivalence is seen as one of the main problems experienced by the subject.

\section{Research Questions}

This study examined the micro sociological processes of a participant for 16 years who was asked to answer the following research questions to investigate the process.

1. What are the processes that have caused the participant to experience ambivalence in recent years?

2. What are the processes that have caused the participant to experience syndrome?

3. What are the inter-subject dialogue processes of the participant based on the concept social dialogue?

\section{Methodology}

In the qualitative research, data about environment, process and perception are mainly collected (Yildırım and Şimşek, 2008). Generally interview, observation and written materials are used to collect these data. In this study, data related to the process were collected. Interviews and written materials were used when the data were collected. These two techniques were used to provide the validity and reliability of the work. Systematic preparation of daily questions is intended to make the written text more reliable. Increasing the validity and reliability of the interview process is supported by observations and data obtained from written documents (Yıldırım and Şimşek, 2008).

This study is longitudinal and idiographic in nature based on qualitative research methods in accordance with this framework mentioned above (Kemmis, 1978). The method of idiographic research is used in social psychology, anthropology and microsociology. The idiographic method explores the specific situations, histories, positions and thoughts of individuals. Thus, idiographic research does not generalize results.. Unlike the nomothetic research technique, there is no tendency to generalize in idiographic studies (Kemmis, 1978). Idiographic studies require an indepth study of individuals or small groups. Idiographic studies can be reinterpreted within the framework of certain theories. In this study, the participants' data were analyzed on the basis of postmodernist and post-structural theories.

\subsection{Participant}

An adult person named Deniz, who had been living in different cities and observed different micro-cultures, participated in the study. A neutral name was chosen because the participant did not want to specify the gender. The study includes a 16-year period. Deniz majored in Architectural Restoration. The participant was asked to keep a diary by asking certain questions at certain intervals and a total of 32 interviews were made with the participant. The participants' experiences starting from the High School were examined.

\subsection{Data Analysis}

Inductive content analysis was applied in the study. The inductive approach examines certain data with specific categories that contain definitions which are difficult to operationalize (Creswell \& Miller, 2000; Creswell \& Poth, 2017). The main concepts of the study were social dialogue, syndrome and ambivalence. With content analysis, the participant's data was examined in detail. The opinions of the two experts and the participants were taken when the analysis was carried out.

\subsection{Results}

This study is longitudinal and idiographic in nature and attempted to interpret the participant's historical processes in which the participant experienced at the micro level. 
Aydoğmuş Ördem, Ö. (2017). Micro sociological syndromes. Journal of Human Sciences, 14(4), $3905-3912$. doi:10.14687/jhs.v14i4.4953

\section{Table 1}

Factors Causing Syndrome

\begin{tabular}{ll}
\hline Psychological Factors Caused by Family & $\begin{array}{l}\text { Fear, Anxiety, Disrespect, Negative Personality } \\
\text { Attribution }\end{array}$ \\
\hline Insufficiency of Micro Environment & Insufficiency of Socialization Process \\
\hline Nomadism & Constant Moving \\
\hline School Inadequacy & Inadequacy of Consulting Process \\
\hline Individual Factors & Lack of a Specific Purpose \\
\hline Academic Skill Inadequacy & $\begin{array}{l}\text { Lack of Conscious Social Environment and } \\
\text { School Inadequacy }\end{array}$ \\
\hline Macro Level Social Problem & Compulsory Transition to Being a Civil Servant \\
\hline Negative Judgments of Micro Environment & Concern for Failure \\
\hline Value Conflict at Macro Level & Disagreement with Traditional Community \\
& Values \\
\hline
\end{tabular}

There were several important factors that led the participant to experience the syndrome. The participant's family seemed to have played a pivotal role in causing her to encounter fear, anxiety, disrespect and negative feedback. Deniz expressed that a negative personality was attributed. Besides the family's negative feedback, the participant was insufficiently involved in social processes and dialogues. Another important factor was constant moving that prevented her from consistent socialization processes. These four processes seemed to have hindered her from specifying a certain goal that would guide the participant into a higher target. In addition, Deniz could not have developed sufficient academic skills because of inconsistent and fragmented school lives. Deniz had to become a civil servant due to the family's pressure. In fact, she never desired to become a regular civil servant. However, the fear of being rejected by the family members and the micro-social environment forced Deniz to accept the job. Apart from all these factors, Deniz tended to oppose the traditional values and roles attributed since the childhood and thus disagreed with traditional community values. Thus, it can be interpreted that these micro-sociological factors created a severe syndrome in the participant.

\section{Interview Findings}

1. What are the processes that caused the participants to experience ambivalence in recent years?

The study has shown that in recent years there has been a serious ambivalence due to events at national and international level. The long period of bureaucratic processes and the existence of intermediary institutions as facilitators have led to ambivalence. The participant has lived in ambivalence in the last four years and found the ambition to come out of ambivalence in another culture. The routine and uncertain life that he has lived for years reveals the need for another cultural orientation. The participant depicts the ambivalence of living and the causes and consequences of this ambivalence as follows:

I've been unemployed for four years. I have no idea what to do or what to do, and I have no idea. I have made the right decisions as I made wrong in my life, for example leaving work was one of the best decisions I made. Yes, I have been in a great ambivalence for 4 years. If I look at this process positively, I think that the damage done to me in my work and childhood is also good for the treatment. On the other hand, there is a weary phenomenon such as ambivalence. There are habits since childhood. It's like taking care of family, relatives and people. From time to time this habit is fluctuating. Sometimes it loses its importance and sometimes it is peaking. Glances, mocking questions, the body language that makes waves make you feel 
Aydoğmuş Ördem, Ö. (2017). Micro sociological syndromes. Journal of Human Sciences, 14(4), $3905-3912$. doi:10.14687/jhs.v14i4.4953

unhappy. In fact, I do not think they are right because of their unhappiness. In the process of this 4 year ambivalence, I think that I will never find the success that I am longing for, the thought that wears me the most. I have values that contradict social values because I am. In short, this 4year period is unclear as well as contradictory for a while, i.e. both healing and hurtful. I have a contradictory wait-and-see process when I will be angry and furious. My motivation is very good; I am able to accomplish this. But when the family and the others get into it, the pains are getting painful. Another thing I cannot get rid of since childhood is fear. This waiting process has also deepened my fears. Fear of failure, which is the end result of effort, effort, is perhaps the greatest.

The long period of ambivalence caused the syndrome to occur in the participant. It can be seen that the negative reactions that may arise from micro and macro translations have further increased the ambivalence of the participant. The high motivation to work and be successful alone can be a sign that you can actually succeed in a positive environment and get rid of the ambivalence syndrome. The negativity of the anxiety and discourse of the microcosm looks to have created the fear that the participant will deepen the syndrome. It depicts how deep the syndrome is when the participant depicts the ambivalence with 'weary' and 'injurious' words.

2. What are the processes that cause the participant to experience syndrome?

It is seen that the participant has the micro environment as the most important factor in the syndrome life. The negative discourse of family, relatives and friends has caused the participant to feel unsuccessful. Firstly, the fact that the family has little confidence in the participant and the negative feedback has caused the participant to do nothing. The lack of adequate support at the level of discourse in the micro environment initially created a low level of difficulty in the participant, but in the following processes the participant began to use the word syndrome instead of the problem word. Thus, the condition of being a syndrome has inactivated the participant and caused the participant to live a chronic syndrome. Indifference, anxiety, feeling of failure, reduced confidence, and negative feedbacks that have been ongoing for many years and caused by micro circulation have led the participants to experience a persistent and chronic syndrome. Participant expressed in part of his diary:

I could not say that I did not like it, because I did not have an atmosphere that respects our thoughts. When we said something we did not think it was humiliation and disdain. I was not someone who made a lot of plans because we had a troubled family life in both material and spiritual matters. I remember when we were very sad about what we found and we were overwhelmed by this situation. We are people with fear.

The above statement of the participant shows how the syndrome lived in the micro environment. The lack of any response to one's own thoughts at the discursive level has led to the chronicity of the problem over the years. As the post-constructionist theory has pointed out in recent years, it sets out intuitive discourses. The dominance of selfish thinking in society can lead to an individual experiencing a syndrome. Participation in dominant discourses and values in the microenvironment may have adversely affected participation. Therefore, there may not be only psychological processes that cause syndrome. Sociologically, discourses can cause individuals to live a syndrome. The insignificance of the dominant discourses leads to the ignorance of the sociological view. This means that micro and macro discourses can help explain and understand the processes in which the subject lives.

3. What are the inter-subject dialogue processes of the participant's social dialogue concept?

In this study, although the participant has interacted with other subjects in the context of social dialogue, the unchanging of his or her thoughts led to perception such as 'you are not like us or you are not us'. In this sense, it was emphasized that the participant's speech was sharp, meaningless and insufficient. Despite the fact that the participant expressed himself in the level 
Aydoğmuş Ördem, Ö. (2017). Micro sociological syndromes. Journal of Human Sciences, 14(4), $3905-3912$. doi:10.14687/jhs.v14i4.4953

of social dialogue and entered a transformative discourse with the micro circles, he was desperate because the traditional family and society values that are expected from the participants at the macro level and discourse have shown their values. Responding to these values and defying these values, the participant stated that he was increasingly lonely. Thus, the social dialogue at the individual level, the fact that institutions such as schools and universities have not developed criticism in the society as a whole has caused the participants to feel alone. In this case, social dialogue can only show that it is not functional at the individual level because the participant felt helpless on both micro and macro level. The lack of social dialogue in the community has spurred participation in non-community dialogue. This non-societal dialogue has taken place through another culture. Therefore, the participant preferred to live in another society abroad and tried to solve this syndromic process in this way. The participant explains the process of social dialogue as follows:

Whenever the subject was opened to the University, they were mocked with us, and they were going to study at the university. In the process starting from our childhood, our mind was always coded because we could not succeed something, so the University thought was always a dream far away for us. There was no knowledge, effort, or struggle for him because I was not able to succeed at all, and I had no idea that there were conscious people in education and a trained instructor around us. No matter how much I talk and express myself, there is no provision. Now it's the only situation I've ever struggled with, being more silent and invisible.

Participants' efforts in social dialogue seem to have failed. The participant has stated that the life that is coded is alive and silent, emphasizing the impossibility of expressing himself. It can be seen that the inability of social dialogue is also in the macro environment, starting from the micro-environment, because the participant states that there is no such dialogue around education. While social dialogue articulated by Falzón was a positive concept, the fact that this concept remained at the individual level caused the participant to remain silent at the very end.

\section{Discussion}

This work focuses on the micro sociological process in which the participant lives through Bauman's (2003) concept of social dialogue in Falzon's (2001) framework of ambivalence. The participant has become more ambivalent because he cannot effectively use the content of the social dialogue concept in his social interactions. In general, the individual is experiencing a feeling of failure in life by experiencing pressure, fear, anxiety and ambivalence under the influence of microcirculation in the plane. In particular, the negative impact of past experiences has had a negative effect on the participants in the following years. Negative feedbacks of microeconomics, adverse effects of macro social structure and participation of the family both negatively affected sociologically and psychologically, negatively affecting participant participation in the gathering. Therefore, the participant preferred to go to another country as an outlet. In this process, the ambiguities that are experienced at national and international level are breaking the participation from social interaction. The participant became isolated and did not contribute to the perception of the participants positively in the social constructs. Hence, it is a psychological syndrome rather than a micro sociological syndrome. Psychological syndromes can be reinterpreted as micro sociological syndromes. In this case, psychological syndromes can be transformed into constructive constructs and expanded towards micro sociology. Negative feedback from the micro and macro environment of the participant and interaction with the negative-pattern constructs push the participant uncertain. Simmel (1999) likewise advocates that society proceeds through dialogue by working with dialectics and antinomies and bases the whole social interaction theory on the dialectic. In this study, the participant likewise enters the process of socialization by experiencing certain problems. However, contrary to the idea of Simmel (1999), the participant has entered into a syndrome that does not go out of its individual history and it seems that Simmel cannot solve the syndromes which the society lived in society, even 
Aydoğmuş Ördem, Ö. (2017). Micro sociological syndromes. Journal of Human Sciences, 14(4), $3905-3912$. doi:10.14687/jhs.v14i4.4953

though the concept of societalism is dialectic. In this sense, Bauman's (2003) concept of ambivalence is thought to be more suited to the framework of this study in terms of describing the syndrome experienced by the participant. Bauman (2003) attaches importance to the concept of alienation as a problem. However, the alienation of the individual into the values of their own society in their own society seems to be a more important problem. The inability of the individual to appear in his / her society and the social dialogue theory can cause the individual to live the syndrome. In this sense, it is not always possible to solve the problems brought by the macro community and the micro-community. Mardin's (2009) Bihruz Bey Syndrome and the micro sociological syndrome of Deniz in this study show similarities even if they are anachronous because subjects alone cannot solve the syndrome. Bihruz Bey lives with a syndrome depending on the factors that arise from the adoption of the western lifestyle at the macro level. French lifestyle and the adoption of luxury consumption explain Bihruz Bey syndrome. Therefore, Mardin (2009) conceptualizes Bihruz Bey, French typification, as Bihruz Syndrome during the modernization process. Social syndromes are a situation that transcends subjects. The widespread use of critical cultures in society and the functional use of the concept of social dialogue can directly affect the subjects positively. The inadequacy of institutions such as schools, universities, families, adult education which will facilitate the problems of the subjects in the society can cause subjects to live syndromes. Durkheim (1992) explains the concept of suicide by taking these social problems further. The next step in the syndrome can be a radical suicide. Durkheim (1992) treats suicide as a suicidal sociological phenomenon by excluding psychological factors. Similarly, the bureaucratic difficulties experienced by individuals in the society, the micro environment, the inadequacy of macro agencies can lead to different syndromes. However, the syndrome can be diagnosed primarily in the microenvironment. Similarly, Foucault (1991) questions the power relationship by addressing a family murder because it is based on a power struggle in which the government will address this murder. If we look at the concept of syndrome in terms of Foucault (1980), the weakness of the subject in the microenvironment and the breakdown of resistance can push the syndrome, suicide or murder.

Researchers such as Durkheim (1992), Bauman (2003), Falzon (2001), Simmel (1999) and Foucault (1980) play an important role in understanding the life style of this syndrome by outlining psychological factors and setting sociological factors. Therefore, the negativities starting from the family and the micro in the first place push into participatory ambivalence and loneliness when combined with the social structure. The participant viewed abroad as a possibility despite all these negative processes.

So, saving individuals from the deterministic approach of sociology is another manifestation of immigration in many societies. One of the causes of migration is the economic, sociological, political, and ideological factors that the individual has experienced in his microcosm and macro-society. The micro-sociological syndrome that starts from Deniz's family can end in search for life in another culture. This micro sociological problem and ambivalence that many individuals live in the postmodern society can turn into syndrome. The solution of a syndrome in this way is also included in the institutions in the society. It is thought that this problem can be solved by enhancing the culture of discussion and social dialogue.

\section{Conclusion}

This study examined the micro sociological processes of a participant over many years in the context of ambivalence, syndrome and social dialogue concepts. The family showed that they did not agree with the values of friends, relatives and general social structure, and that they were in conflict. Social dialogue, syndrome and ambivalence have been interpreted within the framework of the concepts. These three concepts were examined on the basis of postmodernism and poststructuralism theories, showing that the participant's syndrome process cannot be explained only psychologically. Within the discipline of sociology, many researchers and theorists 
Aydoğmuş Ördem, Ö. (2017). Micro sociological syndromes. Journal of Human Sciences, 14(4), $3905-3912$. doi:10.14687/jhs.v14i4.4953

point out that the problems of individuals cannot be reduced to psychological explanations alone. In this sense, subjects of society for greater use of the concept of social dialogue function in a critical culture and may contribute to the positive experience. However, regarding critical thinking education can be added to pre-school and primary school curriculum. Critical thinking workshops in adult education can contribute to the dissemination of the concept of social dialogue. Thus, it can be said that social structure at macro and micro levels may affect individuals beyond psychological explanations because lack of direct democracy and presence of strict bureaucracy in families and institutions may have serious complicated effects on individuals resulting in possible syndromes that need to be dealt with within the discipline of sociology.

\section{References}

Bauman, Z. (2003). Modernlik ve müphemlik. (Çev.İsmail Türkmen), Ayrıntı Yayınları, İstanbul.

Creswell, J. W., \& Miller, D. L. (2000). Determining validity in qualitative inquiry Theory intoPractice, 39(3), 124-131.

Creswell, J. W., \& Poth, C. N. (2017). Qualitative inquiry and research design: Choosing among five approaches. Sage publications.

Durkheim, E. (1992). İntihar. Çev: Ö. Ozankaya). Ankara: Imge Kitabevi.

Falzon, C. (2001). Foucault ve Sosyal Diyalog: Parçalanmanın Ötesi. (Çev. Hüsamettin Arslan). İstanbul: Paradigma Yayınlar1.

Foucault, M. (1991). Annemi, Kızkardeşimi ve Erkek Kardeşimi Katleden Ben Pierre Riviere: 19. Yüzyılda Bir Aile Cinayeti. Çev.: Erdoğan Yuldirm, Ara Yayıncılk, İstanbul.

Foucault, M. (1984). Nietzsche, Genealogy, History. New York: Pantheon.

Foucault, M. (1980). Power and Strategies. New York: Pantheon.

Foucault, M. (2000a). Seçme Yažlar 1. (Çev. Isık Ergüden, Osman Akınhay \& Ferda Keskin). İstanbul: Ayrintı Yayınları.

Foucault, M. (2000b). Seçme Yą̧ılar 2. (Çev. Isık Ergüden \& Osman Akınhay). İstanbul: Ayrıntı Yayınları.

Foucault, M. (2000c). Seçme Yą̧lar 3. (Çev. Isık Ergüden \& Ferda Keskin). İstanbul: Ayrıntı Yayınlar1.

Foucault, M. (2000d). Seçme Yą̧lar 4. (Çev. Isık Ergüden). Istanbul: Ayrıntı Yayınları.

Freire, P. (1970). Pedagogy of the Oppressed, trans. Myra Bergman Ramos. New York: Continuum, 6580.

Inglehart, R., \& Welzel, C. (2005). Modernization, cultural change, and democracy: The buman development sequence. Cambridge: Cambridge University Press.

Kemmis, S. (1978). Nomothetic and idiographic approaches to the evaluation of learning. Journat of Curricutum Studies, 10, 45-5

Mardin, Ş. (2009). Tanzimat'tan Sonra Aşırı Batılliaşma. (Der. M. Türköne ve T. Önder.), Türk Modernleşmesi, İletişim Yayinları, İstanbul.

Newman, S. (2001). From Bakunin to Lacan: anti-authoritarianism and the dislocation of power. Lexington Books.

Parsons, T. (1961). "The Structure of Social Action”, New York: Free Press.

Sarup, M. (1993), An Introductory Guide to Post-structuralism and Postmodernism, Harlow: Harvester Wheatsheaf.

Simmel, G. (1999). Çatışma Fikri ve Modern Kültürde Çatışma, Haz.: Ahmet Aydoğan, İz Yayinc1lik, İstanbul.

Tannen, D. (2007). Talking Voices: Repetition, Dialogue and Imagery in Conversational Discourse. New York: Cambridge University Press.

Williams, J. (2005), Understanding Poststructuralism, Chesham: Acumen

Yıldırım, A., \& Simsek, H. (2008). Nitel Arastirma Yöntemleri. Ankara: Seckin Yayinevi. 